\title{
“Sevgi Bir Kuş" Çocuk Dergisinin Değerler Açısından İncelenmesi
}

\section{Ceylan Tekin Bahrilli $\quad$ Cennet Göloğlu Demir ${ }^{2}$}

\section{Type/Tür:}

Research/Araştırma

Received/Geliş Tarihi: June 19/

19 Haziran 2020

Accepted/Kabul Tarihi:

November 18/ 18 Kasım 2020

Page numbers/Sayfa No: 738-761

Corresponding

Author/İletişimden Sorumlu

Yazar: ceylantekin13@gmail.com

\section{$\checkmark$ iThenticate}

This paper was checked for plagiarism using iThenticate during the preview process and before publication. / Bu çalışma ön inceleme sürecinde ve yayımlanmadan önce iThenticate yazılımı ile taranmıştır.

Copyright $(\odot 2017$ by Cumhuriyet University, Faculty of Education. All rights reserved.

\section{Öz}

Aile, Çalışma ve Sosyal Hizmetler Bakanlığı (AÇSHB) tarafından yayınlanan "Sevgi Bir Kuş" isimli çocuk dergisi engel gözetmeksizin tüm çocukların faydalanabilmesi adına işitsel ve görsel olarak yayımlanmaktadır. Dergi devlet tarafından korunma ve bakım altındaki çocukların bulunduğu sevgi evleri ve çocuk evleri sitelerine ücretsiz olarak gönderilmektedir. Değerler bireylerin inançlarını, tutumlarını ve davranışlarını etkileyen olgulardır. Bireylerin davranışları erken yaşlarda şekillenmektedir. Dolayısıyla okul öncesinden başlayarak çocuklara değerlerin doğru bir şekilde kazandırılması önemlidir. Bu noktada aile, okul öncesi ve sonrası eğitim kurumları ile birlikte çocuk dergilerinin ve çocuk kitaplarının değerlerin kazandırılmasındaki önemi yadsınamaz. Bu araştırmada "Sevgi Bir Kuş" isimli çocuk dergisinin 2015-2020 yılları arasındaki sayıları içerisinde yer alan hikâye, masal ve çizgi roman edebi türlerindeki değerlerin belirlenmesi amaçlanmıştır. Değerleri belirlemek amacıyla doküman incelemesi yöntemi kullanılmıştır. Araştırma sonucunda 32 yazın türünde toplam 29 farklı değere ulaşılmıştır. 29 farklı değerin yazı türlerinde toplamda 226 defa yer aldığ $\breve{1}$ tespit edilmiştir. Bu değerlerden sevgi, nezaket, vatanseverlik ve paylaşmak değerleri en çok yer alan değerler olmuştur. Barış, hoşgörü, milli birlik, adil olma, sağlık, temizlik ve sabır en az yer alan değerler olmuştur. Bu bağlamda ailede değerlerin kazandırılması açısından dezavantajlı olan korunma ve bakım altında bulunan çocuklara ulaştırılan dergideki edebi türlerin içeriğinin değerler açısından zenginleştirilmesi ve içerikler hazırlanırken değerlerin dikkate alınması önerilmiştir.

Anahtar Kelimeler: Değerler, değerler eğitimi, çocuk dergisi, korunmaya muhtaç çocuklar, edebi tür

\section{Suggested APA Citation/Önerilen APA Atıf Biçimi:}

Tekin Bahrilli, C., \& Göloğlu Demir, C. (2021). "Sevgi bir kuş” çocuk dergisinin değerler açısından incelenmesi. Cumhuriyet International Journal of Education, 10(2), 738-761.

http://dx.doi.org/10.30703/cije.755312

\footnotetext{
${ }^{1}$ Çocuk Gelişimci, Aile Çalışma ve Sosyal Hizmetler Bakanlığı, Balıkesir/Türkiye Child Development Specialist, Ministry of Family, Labour and Social Services, Balikesir/Turkey e-mail: ceylantekin13@gmail.com ORCID ID: orcid.org/0000-0003-1410-7004
}

2 Dr. Öğr. Üyesi, Bandırma Onyedi Eylül Üniversitesi, Sağlık Bilimleri Fakültesi, Çocuk Gelişimi Bölümü, Balıkesir/Türkiye Asst. Prof. Dr, Bandirma Onyedi Eylul Univesity, Faculty of Health Sciences, Department of Child Development Balikesir/ Turkey e-mail: gologlu.cennet@gmail.com ORCID ID: orcid.org/0000-0002-8770-6107 


\title{
An Investigation of the Children's Magazine "Sevgi Bir Kuş" In Terms of Values
}

\begin{abstract}
The children's magazine "Sevgi Bir Kuş" issued by the Ministry of Family, Labour and Social Services is published audibly and visually so that all children can benefit regardless of disabilities. The magazine is sent free of charge to the love and child housing sites where children are under protection and cared by the state. Values are facts that affect individuals' beliefs, attitudes and behaviors. Individuals' behaviors shape at an early age. Therefore, it is important to provide children with correct values starting from preschool. At this point, the importance of child magazines and children's books in gaining values besides family, pre-school and post-educational institutions cannot be denied. In the current study, it is aimed to determine the values in the literary genres of stories, folk tales and comics in the issues of the children's magazine "Sevgi Bir Kuş" published between the years 2015 and 2020. The document analysis method was used to determine the values. As a result of the study, a total of 29 different values were reached in 32 different types of texts. These 29 different values were found to be mentioned 226 times in the analyzed genres. The most frequently repeated values were found to be love, kindness, patriotism and sharing. The least repeated values were found to be tolerance, national solidarity, being just, cleanliness and patience. Thus, it is suggested to enrich the content of literary genres in terms of these values and to consider the values when preparing the contents.
\end{abstract}

Keywords: Values, values education, children's magazine, story, children in need of protection, literary genre

\section{Giriş}

Değerler, toplumsal yapıda ve insan ilişkilerinde düzenin sağlanması için temel kuralları içerir. Bu nedenle toplumlar değerin önemini göz ardı edemezler ve sahip oldukları değerleri nesiller arası aktararak devamlılıklarını sağlamaya çalışırlar. Değer kavramı sosyoloji, felsefe ve psikoloji gibi birçok alanda araştırmacılar tarafından incelenmiş ve tanımlanmaya çalışılmıştır (Candan ve Ergen, 2004, s.135; Demirtaş, 2009 , s.4). Haselat ve Taylor (2000) değeri, belirli eylemlerin iyi ve arzu edilir olduğuna karar veren standartlar, davranışlara rehberlik eden ilkeler ve temel inançlar olarak ifade eder. Değerleri evrensel ve toplumsal değerler olarak ayırabilmek mümkündür. Evrensel değerler, dünyanın her yerinde kabul görmüş sevgi, çalışkanlık, cesaret, sayg1, yardımseverlik gibi değerlerdir. Toplumsal değerler ise toplumdaki değişime, dönüşüme ve ilerlemeye göre değişebilmektedir (Gündoğdu, 2010; Hökelekli, 2010). Değerler birbiri arasında bir bütün halindedir, ayrı düşünülemezler. Oluşturulan bu bütünlük değerler sistemi olarak ifade edilir (Kaymakcan, 2010, s.11). Bu sistem içerisinde yer alan değerler birçok araştırmacı tarafından farklı şekillerde sinıflandırılmıştır. En çok benimsenen sınıflamaların ise Rokeach, Schwartz ve Spranger'a ait olduğu görülmektedir (Sapsağlam, 2015; Yazıc1, 2006; Yiğittir, 2012).

Schwartz Türkiye' nin de içinde bulunduğu altmışın üstünde ülkede değerleri on sınıfta toplamıştır. Bu sınıflamalar altında; becerikli olmak, sözü geçen biri olmak, otoriter olmak, zengin olmak; hayattan zevk almak, heyecan verici farklı hayatlara sahip olmak, yaratıcı olmak, özgür olmak, barışçıl bir dünya, sosyal adalet, eşitlik, dürüst olmak, yardımsever olmak, mütevazı olmak, geleneğe saygı duymak, nazik olmak, disiplinli olmak, büyüklere saygılı olmak, milli güvenlik, aile güvenliği, temiz olmak, sağlıklı olmak gibi değerler bir araya getirilmiştir (Schwartz, 1996, s.122-123). UNESCO değerleri 12 evrensel değer olarak sınıflamıştır. Bu değerler özgür olmak, 
dürüst olmak, yardımlaşmak, sevgi, alçakgönüllü olmak, saygılı olmak, mutlu olmak, sorumluluk sahibi olmak, birlik olmak, barış, sade olmak ve tolerans sahibi olmaktır. (Unesco, 2020).

Toplumsal huzurun devam edebilmesi için gelecek nesillere değerlerin aktarılması gerekir. Aktarılan bu değerlerin çocuklar ve gençler tarafından davranışa dönüştürmeleri beklenir. Bu nedenle çocuklara yönelik değerler eğitimine erken yaşlarda başlanması gerekir (Bolat, 2016; Güçlü, 2015 ). Çocukluktan itibaren değerleri kazandırmanın birçok farklı yöntemi bulunmaktadır. Bu yöntemlerin bazıları değerlerin doğrudan öğretimini, bazıları ise bireyin akıl yürüterek ve sorgulamalar yaparak düşünüp karar vermesini desteklemeye yöneliktir (Doğanay, 2006). Değerlerin öğretilmesi konusunda yapılan çalışmalarda, karakter eğitimcilerinden Wynne ve Ryan, Molnar ve Lickona değerlerin öğretiminde hikâyelerden faydalanılması gerekliliğini iddia ederken; ahlaki akıl yürütmenin savunucularından Kohlberg tartışma ortamı ve adil grupların oluşturularak değerlerin öğretiminin yapılabileceğini savunmuştur (Halstead ve Taylor, 2000).

Tökel'e (2005) göre edebiyat çocuk eğitimi konusunda kullanılan çok önemli araçlardan biridir. Edebiyat çocukları doğrudan eğitmeyi amaçlamasa da çocuklar üzerinde olumlu etkiler bırakır. Çocuğun kendisini ve çevresini algılamasına, yeni davranışlar geliştirmesine katkı sağlar (Karatay, 2007, s.466). Özdaş'a (2018) göre edebiyat, toplumun değerlerini aktarabilen en iyi alan olarak düşünülebilir. Edebi türlerin birçoğu topluma ait değerleri bir sonraki nesile aktarmada köprü görevindedir. Bu özelliği ile edebi türlerle eğitim iç içedir (Grenby ve Reynolds, 2011, s.1). Bu bağlamda çocuklar için yaş ve düzeylerine uygun hazırlanan edebi türler çocukların değerler ile tanışmasına, bu değerleri keşfetmesine ve kahramanlar aracılığıyla içselleştirmesine katkı sağlar (Çengelci ve Eryılmaz, 2018, s.68). Hikâye ve masal türleri erken çocukluk döneminde çocuklara değerlerin kazandırılmasında önemli bir yere sahiptir (Mendoze ve Reese,2001). Masallar geçmişteki günlük yaşamı, düğün ve bayram gibi önemli günleri, sosyo kültürel ilişkileri inceleyip geçmiş hakkında ipuçları vermektedir. Bu yönüyle masallar geçmiş ve gelecek arasında köprü kurarak milli ve kültürel değerlerin nesiller arası aktarılmasında önemli bir araç olarak kullanılır (Sever, Memiş ve Sever, 2015 ; Erdal, 2016). Hikayeler de diğer türlere göre daha kısa ve öz olmaları, gerçek yaşama yakın olayları anlatmaları nedeniyle değerlerin açık şekilde aktarılmasını sağlamaktadır (Emek, 2010; Demir, 2012). Edebi türler arasında özellikle masal, ulusal ve evrensel değerlerin nesiller arasında aktarılmasında ve toplumdaki ahlaki değerlerin çocuklara eğlenerek benimsetilmesinde önemli bir göreve sahiptir (Karatay, 2007). Bu yüzden çocuklar ve gençleri edebi metinlerle bir araya getirmek değerlerin kazandırılmasında en etkili yöntemlerden biridir. Ders verici edebi metinler çocuk ve gençleri yanlış duygu ve düşüncelerden uzaklaştırıp doğruya sevk etmektedir. Yaşamda herhangi bir tecrübesi bulunmayan çocuklara iyilik, hoşgörülük, doğruluk gibi değerler benimsetilmeye çalışırken "bunu yap", "şunu yapma" şeklinde kullanılan emir ifadeleri çocuğa istenilen değeri kazandırmak yerine çocukta bıkkınlık oluşturabilir. Bunun yerine çocuklara kazandırılmak istenen değere yönelik edebi türler okunup/okutulup çocuğun kahramanla kendisini özdeşleştirmesi sağlanarak çocuğa istenen değer kazandırılabilir (Gönenç, 2015, s.137-139). 
Bu bağlamda çocukların ilgi ve ihtiyaçlarına yönelik masal, fıkra, hikâye, çizgi roman, bulmaca ve bilmece gibi farklı edebi türlerin yer aldığı düzenli aralıklarla yayınlanan çocuk dergileri (Gezmen, 2018, s.61) değerlerin kazandırılmasında önemli bir araç olarak karşımıza çıkmaktadır. Çocuk dergileri çocukların gelişimlerini, eğitim ve öğretimlerini, kendilerini keşfetmelerini, topluma uyum sağlamalarını destekleyen ve yetişkin değerlerini uygun şekilde çocuklara aktaran önemli bir materyaldir (Chick ve Hunter, 2009; Oğuzkan, 2001). Halstead ve Taylor'a (2000) göre çocuklar erken yaşlarda değerleri ailelerinde öğrenmeye başlasa da sonrasında medyadan, arkadaşlarından, oyun oynadıkları gruplardan, bakımını sağlayan diğer bireylerden, ait olduğu toplumdan ve diğer araçlardan (kitap, dergi gibi) değerleri öğrenebilir. Çocuk dergilerinde yer alan çeşitli edebi türler çocuklara iletilmek istenen mesajın daha eğlenceli şekilde ulaşmasını sağlamaktadır (Alabaş ve Kamer, 2016). Aynı zamanda bu metinlerde işlenen konular çocuklara evrensel ve milli değerler hakkında önemli ipuçları vermektedir (Çelikpazu ve Aktaş, 2011, s.416).

Literatürde farklı dönemlerde yayınlanan çocuk dergileri değerler açısından araştırmalara konu olmuştur. Akbayrak (2014) tarafından erken Cumhuriyet dönemine ait çocuk yayınlarından "Mektepli Gazetesi, Çocuk, Çocuk Sesi Dergileri” biçim ve içerik açısından analiz edilmiştir. Analiz sonucunda çocuk dergilerinin değer aktarımında olumlu etkisi olduğu sonucuna ulaşılmıştır. Balcı (2017), 1923 yılında yayın hayatına başlayan "Çocuklarla Rehber" dergisini incelemiştir. İnceleme sonucunda dergilerde yer alan neredeyse tüm metinlerde toplumun kabul gördüğü dini ve ahlaki değerler yer aldığı görülmüştür. Gurbetoğlu (2007) tarafından “II. Meşrutiyet Dönemi Çocuk Dergileri" masal, hikâye, fıkra, makale, şiir gibi edebi türler ahlaki eğitim ve ahlaki değerler yönünden incelenmiştir. Dergide yer alan edebi türlerden özellikle hikâye ve masal türlerinde örnek kahramanlar ile çocuklara dini ve milli değerlerin yanı sıra evrensel değerlerin de yer aldığı sonucuna ulaşılmıştır. Benzer araştırmalarda Alabay, Kandemir ve Güney (2018) Meraklı Minik (TÜBİTAK) dergisini, Kılcan ve Üçarkuş (2018) Eğitim Bilişim A ğı (EBA) dergilerini, Yılmaz ve Duman (2018) ise TRT Çocuk dergisini değerler açısından incelemiştir.

Geçmişten günümüze yayınlanan çocuk dergilerinde işlenen değerler farklılaşsa da değerlerin aktarılmasında çocuk dergilerinin önemli bir araç olduğu göz ardı edilemez. Bu araştırma kapsamında incelenen "Sevgi Bir Kuş" isimli çocuk dergisi (AÇSHB, 2020a) içerik olarak diğer çocuk dergileriyle benzerlik göstermekle birlikte dergiyi önemli kılan çeşitli özellikleri bulunmaktadır. Türkiye'de korunma ve bakım altında olan 14.214, görme engelli olan 44.409 ve işitme engelli olan 36.407 çocuk bulunmaktadır (AÇSHB, 2020b) . "Sevgi Bir Kuş" çocuk dergisine korunma ve bakım altındaki çocukların bulunduğu sevgi evleri ve çocuk evleri sitelerinde ücretsiz olarak basılı formda erişilmekte iken işitme engelli çocukların yararlanabilmesi için işaret dilinde, görme engelli çocukların yararlanabilmesi için ise sesli betimleme şeklinde elektronik ortamda erişilebilmektedir. Bu bağlamda "Sevgi Bir Kuş" adlı çocuk dergisinin dezavantajlı ve özel gereksinimli çocukların erişime uygun olması araştırmacılar tarafından değerlerin incelenmesi kapsamında önemli görülmüştür. Ayrıca çocuklar anne ve babasını model alarak yeni davranışlar öğrenir ve aile arasındaki iletişimin artmasıyla çocuğun değerlere yönelik yeni deneyimler yaşaması sağlanır (Balat, 2012). Sonuç olarak ailelerinden ayrı AÇSHB' ye bağlı korunma altında 
bulunan 0-18 yaş arası çocukların yaşadıkları kuruluşlara gönderilen "Sevgi Bir Kuş" adlı derginin değerler açısından incelenmesi oldukça önem arz etmektedir.

\section{Araştırmanın Amacı}

$\mathrm{Bu}$ araştırmanın amacı AÇSHB tarafından yayınlanan "Sevgi Bir Kuş" isimli çocuk dergisindeki hikâye, masal ve çizgi roman edebi türlerinde yer alan değerlerin neler olduğu ve bu değerlere ne derecede yer verildiğinin belirmesidir.

\section{Yöntem}

Nitel araştırma deseninde tasarlanan çalışmada AÇSHB tarafından yayınlanan "Sevgi Bir Kuş" isimli çocuk dergisindeki hikâye, masal ve çizgi roman edebi türlerinde yer alan değerleri belirlemek amacıyla doküman incelemesi yöntemi kullanılmıştır. Doküman incelemesi, araştırılması hedeflenen olgu ve olgular hakkında bilgi içeren yazılı ve görsel materyallerin analizidir (Yıldırım ve Şimşek, 2018 s. 189 ).

\section{Veri Kaynağı ve Çalışma Grubu}

AÇSHB tarafından yayınlanan "Sevgi Bir Kuş" isimli çocuk dergisi incelenmiştir. Derginin ilk sayısı 2015 yılında basılmış olup yılın belli aralıklarında yayınlanmaktadır. 2015 yılından 2020 yılına kadar yedi sayı basılmıştır. Dergilere AÇSHB' nin resmi internet sitesinden ulaşılmıştır. Dergilerde edebi olan ve olmayan yazılara yer verilmektedir. Uzman görüşleri doğrultusunda dergilerde yer alan yazı türlerinden hikâye, masal ve çizgi romanların değerler açısından analiz edilmesinin uygun olacağı düşünülmüştür. Dergilerin tamamındaki yazı türleri incelendiğinde 17 hikâye, altı masal ve dokuz adet çizgi romanın araştırma kapsamında ele alınması uygun görülmüştür.

\section{Verilerin Analizi}

Nitel araştırmalarda araştırmacının; araştırmanın ve toplanan verilerin özelliklerinden yola çıkarak ve mevcut veri analiz yöntemlerini gözden geçirerek kendi araştırması için bir veri analiz planı geliştirmesi beklenir (Yıldırım ve Şimşek, 2018, s.237). Bu sebeple ilgili alan yazındaki benzer araştırmalardaki analiz yöntemleri incelenerek (K1lıç ve Aktan, 2015) ve içerik analizine benzer şekilde araştırmacılar tarafından veri analiz planı geliştirilmiştir. Değerlerin tespit edilmesinde sırasıyla aşağıdaki işlemlere yer verilmiştir:

1. Hikâye, roman ve çizgi roman içinde değer ifade eden paragraf/bölümler tespit edilmiştir.

2. Değer ifade eden paragraf/bölümlerdeki değer vurgusunun belirgin olduğu cümleler tespit edilmiştir.

3. Tekrar, tekrar yapılan incelemelerden sonra değer ifadesi net olmayan cümleler veri setinden çıkarılmıştır. Bu aşamada uzman görüşlerine başvurulmuştur.

4. Değer ifade eden cümlelerin temsil ettiği değer veya değerler kodlanmıştır. Bu aşamada görüş ayrılıkların olduğu durumlarda uzman görüşüne başvurulmuştur.

5. Elde edilen değerler uzman görüşleri ve TDK sözlüğü dikkate alınarak anlam bakımından yakın veya ilişkili olduğu düşünülen değerler olarak gruplandırılmıştır.

6. Gruplanan değerler, hikâye, masal ve roman yazı türlerinde kaç defa yer aldığına yönelik frekanslar ve doğrudan alıntılarla sunulmuştur. 
Bu doğrultuda çalışma grubunda yer alan her hikâye, roman ve çizgi roman ayrıntılı okunarak, değerler tespit edilmeye çalışılmıştır. Tablo 1'de incelenen masal ve çizgi romanlar verilmiştir.

Tablo 1

İncelenen Hikâye, Masal ve Çizgi Romanlar

\begin{tabular}{|c|c|c|}
\hline Yazım Türü & Başliklar & Dergi Sayısı \\
\hline \multirow{18}{*}{ Hikâye } & Kurk Yusuf, & Sayı 1 \\
\hline & Eden Bulur; Kuş ve Yilan & Say1 2 \\
\hline & Gül Bahçesi & Say1 2 \\
\hline & Artık Canımız Sıkılmıyor Kardeşim & Say1 2 \\
\hline & Tüccar Öküz & Say1 3 \\
\hline & Zeytin Ağacı & Say1 3 \\
\hline & Kafesteki Turkuaz & Say1 4 \\
\hline & Dedemin Kırmızı Mızıkası & Say1 4 \\
\hline & Mevlana'nın Gönül Müziği Aşk & Say1 4 \\
\hline & Doğrular Defteri & Say1 5 \\
\hline & Yellice'nin Üveyikleri & Say1 5 \\
\hline & Kayı İnek & Sayı 5 \\
\hline & Neşeli Palamutlar & Sayı 6 \\
\hline & Benim Babam Bisiklete Benziyor & Say1 6 \\
\hline & Mehmet'in Babası & Say1 6 \\
\hline & Evlat Babanin Sirrıdır & Say1 6 \\
\hline & Dedemden Anneme Miras & Say1 7 \\
\hline & Karanfil & Say1 1 \\
\hline \multirow{8}{*}{ Masallar } & Baliş'in Oyunları & Say1 2 \\
\hline & Ağabey Olmak İsteyen Küçük Zürafa & Say1 3 \\
\hline & Hakan Şebek ile Atı & Say1 4 \\
\hline & Örme Yüzük & Say1 5 \\
\hline & Kâğıt İcadı Nasıl Oldu? & \\
\hline & Ebru & Say1 1 \\
\hline & Kadim Dede; Malazgirt Zaferi & Sayı 1 \\
\hline & Kadim Dede; Osman Gazi'nin Rüyası - Osmanlı'nın Kuruluşu & Say1 2 \\
\hline \multirow[t]{6}{*}{ Çizgi roman } & Kadim Dede; Çanakkale'de Bir Bayram Sabahı & Sayı 3 \\
\hline & Kadim Dede; Ay Yıldızlı Bayrağımızın Hikâyesi & Say1 4 \\
\hline & Kadim Dede & Say1 5 \\
\hline & Kadim Dede & Say1 6 \\
\hline & Güven Usta & Say1 7 \\
\hline & Kadim Dede & Say1 7 \\
\hline
\end{tabular}

\section{Geçerlik ve Güvenirlik Çalışması}

Araştırmanın geçerliliği (inandırıcılık ve aktarabilirlik) uzun süreli etkileşim, derin odaklı veri toplama, uzman incelemesi ve ayrıntılı betimle ile sağlanmıştır (Yıldırım ve Şimşek, 2018). Bu kapsamda sırasıyla; uzun süreli etkileşimi sağlamak amacıyla hikâye, roman ve çizgi romanlar tekrar tekrar okunarak veriler ayrıntılı olarak işlenmiştir. Değerlerin net olmadığı durumlarda ise belirlenen metinlerin tamamımı tekrar okunmuştur ve uzman görüşleri alınmıştır. Dolayısıyla veriler üzerinde uzun süreli incelemeler yapılmıştır. Derin odaklı veri toplama kapsamında en net değer ifadelerine ulaşılıncaya kadar tekrarlı okumalar yapılmıştır. Ham verilere bağlı kalınarak her değer için, metinlerden doğrudan alıntılar yapılarak veriler betimlenmiştir. Araştırmacılar tarafından kodlanan verilerin, güvenirliği sağlamak 
amacıyla üç uzman görüşüne başvurulmuştur. Miles ve Huberman'nın güvenirlik formülü kullanılmıştır.

$$
\begin{gathered}
\text { Uzlaşma Yüzdesi }=\frac{\text { Görüş Birliği }}{\text { Görüș Birliği+Görüş Ayrılı̆̆ı }} \times 100 \\
\text { Uzlaşma Yüzdesi }=\frac{207}{226} \times 100=91,59
\end{gathered}
$$

Güvenirlik hesaplarının \% 80'in üzerinde çıkması, araştırma için güvenilir kabul edilmektedir (Miles ve Huberman, 1994, s.64). Elde edilen değer verilerin güvenir olduğunu göstermektedir.

\section{Bulgular}

Bu bölümde dergilerde yer alan yazı türlerinden hikâye, masal ve çizgi romanlarda işlenen değerler hakkında yapılan analiz sunulmuştur. Yazı türlerinden 17 hikâye, altı masal ve dokuz adet çizi roman incelenmiştir. Anlam bakımdan yakın olan değerler gruplanarak, gruplar içerisinde tek tek ele alınmıştır. Değerlere örnek verebilmek amacıyla yazı türlerinden doğrudan alıntılar yapılmıştır.

\section{Sevgi, Doğa Sevgisi, Misafirperverlik ve Aile Birliği Değerleri}

Sevgi, doğa sevgisi, misafirperverlik ve aile birliği değerlerinin dergilerde bulunan yazı türlerinde yer alma durumları, Tablo 1'de verilmiştir.

Tablo 1

Sevgi, Misafirperverlik ve Aile Birliği Değgrleri

\begin{tabular}{lcccc}
\hline & \multicolumn{3}{c}{ Yazı Türleri } & Toplam \\
\cline { 2 - 4 } Değerler & Hikâye & Masal & Çizgi Roman & 50 \\
\hline Sevgi & 37 & 7 & 6 & 5 \\
Misafirperverlik & 2 & - & 3 & 5 \\
Aile Birliğine Önem & 3 & - & 2 & 60 \\
Verme & & 7 & 11 & \\
Toplam & 42 & &
\end{tabular}

Tablo 1'de yer alan sevgi, doğa sevgisi, misafirperverlik ve aile birliği değerlerine toplam 60 kez yer verilmiştir. Bu grupta sevgi $(\mathfrak{f}=50)$ değerinin en fazla yer aldığı, sonrasında misafirperverlik $(f=5)$ ve aile birliğine önem verme $(f=5)$ değerinin takip ettiği görülmektedir. Sevgi değeri yazı türlerinden hikâyelerde $(f=37)$, masallarda $(f=7)$ ve çizgi romanlarda $(f=6)$ defa yer almıştır. Sevgi değeri ile ilgili doğrudan alıntılara aşağıda yer verilmiştir:

"Mevlâna her ne kadar ilmiyle ünlense de gönlünde onun da bir türlü anlayamadığı, boşluğunu dolduramadı̆̆ı bir eksiği vardı; aşk." (Mevlana'nın Gönül Müziği; Aşk, Say1 4, s.41).

"Neşeli Meşe bu sefer palamutlara "Peki ne kadar seviyorsunuz?" diye sormuş.

Palamutlar düşünüp taşınmış, sırayla konuşmaya başlamışlar.

Merakl Palamut:

-Ben seni gökyüzündeki yıldızlar kadar çok seviyorum babacığım, demiş.

Gözlüklü Palamut:

-Ben seni gövdendeki yapraklar kadar çok seviyorum, diye yanıtlamış.

Çalışkan Palamut: 
-Babacığım, ben seni her gün kullandığımız harfle ve kelimeler kadar çok seviyorum, demiş"(Neşeli Palamut, Sayı 6, s.5).

"...Karanfil çiçeğinin kokusunu çok sevdiğinden annesi ona bu ismi vermiş"(Karanfil, Sayı 1, s.22).

Sevgi değeri incelenen yazı türlerinde, insanları sevmek, insanlar tarafından sevilmek, anne babayı sevmek, evladı sevmek, hayvanları sevmek, bitkileri sevmek, sanatı sevmek, insanlık için faydalı olan bilgin kişileri sevmek, hakikat olanları sevmek, Allah tarafından yaratılan her şeyi sevmek, Allah'1 sevmek, peygamberi sevmek, sevginin gönülde olduğunu bilmek, sevgiyle her şeyin üstesinden gelebilmek, ilahi sevgiye ulaşmak, sevmeyi öğrenmek, gönüldeki sevgiyi ölçememek, sevginin çoğalarak arttı̆̆ı boyutlarıyla ele alınmıştır.

Misafirperverlik değeri yazı türlerinden hikâyelerde $(\mathrm{f}=2)$ ve çizgi romanlarda $(\mathrm{f}=3)$ defa yer almıştır. Misafirperverlik değeri ile ilgili doğrudan alıntılara aşağıda yer verilmiştir:

"Bilgiye bu kadar hevesli bir gencin yanında vakti unutuyorum. Artık yola çıklmaz oğul! Bu gece misafirimiz olursan seviniriz. Osman Gazi sohbetten sonra kendine ayrılan misafir odasına geçtiğinde yatması için bir döşek, odayı aydınlatan bir mum, yerde bir rahle ve duvarda asılı bir Kur'an-ı Kerim görür"(Kadim Dede, Sayı 2, s.32).

Misafirperverlik değeri incelenen yazı türlerinde, misafire değer vermek, misafir ağırlamayı sevmek, misafir için hazırlık yapmak, misafiri dinlemek, misafirin sorunlarına çözüm, doğadaki canlıları evinde misafir etmek, hayvanları tanrı misafiri olarak görmek bulmaya çalışmak şeklinde ele alınmıştır.

Aile birliğine önem verme değeri yazı türlerinden hikâyelerde $(f=3)$ ve çizgi romanlarda $(\mathrm{f}=2)$ defa yer almıştır. Aile birliğine önem verme değeri ile ilgili doğrudan alıntılara aşağıda yer verilmiştir:

"Enes ve Rana ise anne ve babasıyla kasabanın bağhı olduğu ilde yaşıyorlardı. Kasaba şehre yakın olduğu için neredeyse her hafta sonu dedelerinin yanlarma gelirler, hem dedelerinin yalnızlığın paylaşırlar hem de dedelerine bahçe işlerinde yardım ederlerdi

"(Gül Bahçesi, Sayı 2, s.31).

Aile birliğine önem verme değeri incelenen yazı türlerinde, aile bireyleriyle bir şeyler yapmak, aile büyüklerine önem vermek, aile büyüklerini sık sık ziyaret etmek, aile bireylerini sevmek, aile bireyleri ile vakit geçirmek, aile bireylerini özlemek şeklinde ele alınmıştır.

\section{Arkadaşlık, Dostluk, Barış ve Kardeşlik Değerleri}

Arkadaşlık, dostluk, barış ve kardeşlik değerlerinin dergilerde bulunan yazı türlerinde yer alma durumları, Tablo 2' de verilmiştir.

Tablo 2

Arkadaşlık, Dostluk, Barış ve Kardeşlik Değerleri

\begin{tabular}{lcccc}
\hline & \multicolumn{3}{c}{ Yazı Türleri } & \\
\cline { 2 - 4 } Değerler & Hikâye & Masal & Çizgi Roman & Toplam \\
\hline Arkadaşlık & 5 & 2 & 1 & 8 \\
Dostluk & 1 & - & 2 & 3 \\
Kardeşlik & 1 & 1 & - & 2 \\
Barış & - & - & 1 & 1 \\
Toplam & 7 & 3 & 4 & 14 \\
\hline
\end{tabular}


Tablo 2' de yer alan arkadaşlık, dostluk, barış, kardeşlik değerlerine toplam 14 kez yer verilmiştir. Bu grupta arkadaşlık $(f=8)$ değerinin en fazla yer aldığ 1 , sonrasında dostluk ( $f=3)$, kardeşlik ( $f=2$ ) ve barış $(f=1)$ değerinin takip ettiği görülmektedir.

Arkadaşlık değerin yazı türlerinden hikâyelerde $(f=5)$, masallarda $(f=2)$ ve çizgi romanlarda ( $\mathrm{f}=1)$ defa yer almıştır. Arkadaşlık değeri ile ilgili doğrudan alıntılara aşağıda yer verilmiştir:

"...Çevresinde onun değerini anlayan ve her nereye gitse onun yanında gitmeye can atan birkaç arkadaşı da varmış"( Kırk Yusuf, Sayı 1, s.12).

Arkadaşlık değeri incelenen yazı türlerinde, arkadaşlarla bir şeyler paylaşmak, oyunlar oynamak, birlikte zaman geçirmek, arkadaşla hep bir arada olma isteği, arkadaşlığın değeri, zor zamanlarda arkadaşlara destek olmak, arkadaşlarla sorunları paylaşabilmek, farklı canlı türleriyle arkadaş olabilmek şeklinde ele alınmıştır.

Dostluk değeri yazı türlerinden hikâyelerde $(f=1)$ ve çizgi romanlarda $(f=2)$ defa yer almıştır. Dostluk değeri ile ilgili doğrudan alıntılara aşağıda yer verilmiştir:

"Evlatlarım, biliyor musunuz? Bizim çalıkuşu sizler için kendini feda etti. Şimdi onun bizden ne farkı var?

-O bizim dostumuzdu. Onu bir kabre yerleştirelim ki fedakârlığı unutulmasin."(Kadim Dede, Say1 6, s.35).

Dostluk değeri incelenen yazı türlerinde, dostlarla bir şeyler paylaşmak, dostların kalbini kırmamak, hayvanlarla dost olmak, dostların kıymetini bilmek olarak ele alınmıştır.

Kardeşlik değeri yazı türlerinden hikâyelerde $(f=1)$ ve masallarda $(f=1)$ defa yer almıştır. Barış değeri yazı türlerinden yalnızca hikâyelerde $(f=1)$ defa yer almıştır Kardeşlik ve barış değerine yönelik doğrudan alıntılara aşağıda yer verilmiştir:

"Kafesten kurtulduğum ilk gün, kanatlarımdaki sevginin gücüyle bütün dünyadaki kuşlara barışı, kardeşliği taşımaya yemin ettim"(Kafesteki Turkuaz, Sayı 4, s.11).

Kardeşlik değeri incelenen yazı türlerinde, arkadaşlarını kardeş kadar sevmek, sürekli bir arada olmayı istemek, birlik beraberlik halinde barış içinde kardeş gibi yaşamak olarak ele alınmıştır. Barış ise, kendi vatanın da özgürce yaşayabilmek, hiçbir ayrım yapmadan tüm dünyaya barışı getirmek, barış için çabalamaktan vazgeçmemek şeklinde ifade edilmiştir.

\section{Sayg1, Nezaket, Hoşgörü ve Alçak Gönüllülük Değerleri}

Saygı, nezaket, hoşgörü ve alçak gönüllülük değerlerinin dergilerde bulunan yazı türlerinde yer alma durumları, Tablo 3 'te verilmiştir.

Tablo 3

Saygı, Nezaket, Hoşgörü ve Alçak Gönüllülük Değerleri

\begin{tabular}{lcccc}
\hline & \multicolumn{3}{c}{ Yazı Türleri } & \\
\cline { 2 - 4 } Değerler & Hikâye & Masal & Çizgi Roman & Toplam \\
\hline Saygi & 5 & 2 & 3 & 10 \\
Nezaket & 10 & 3 & 14 & 27 \\
Hoşgörü & 1 & - & - & 1 \\
Alçak Gönüllülük & 3 & - & - & 3 \\
Toplam & 19 & 5 & 17 & 41 \\
\hline
\end{tabular}


Tablo 3'te yer alan saygı, nezaket, hoşgörü ve alçak gönüllülük değerine toplam $41 \mathrm{kez}$ yer verilmiştir. Bu nezaket $(\mathrm{f}=27)$ değerinin en fazla sonrasında grupta sayg1 (10), alçak gönüllük $(\mathrm{f}=3)$ ve hoşgörü $(\mathrm{f}=1)$ değerinin takip ettiği görülmektedir.

Saygı değeri yazı türlerinden hikâyede $(\mathfrak{f}=5)$, masalda $(\mathfrak{f}=2)$ ve çizgi romanda $(\mathrm{f}=3)$ defa yer almıştır. Saygı değeri ile ilgili doğrudan alıntılara aşağıda yer verilmiştir:

"Doğadaki her varlı̆̆ın Tanrı'nın nuru olduğunu bilir, bir karncadan bir buğday tanesine kadar saygi ve sevgi duyarmıs"(Kırk Yusuf, Sayı 1, s.10).

"...Ananı, atanı say; bereket büyüklerledir"(Kadim Dede, Sayı 2, s.34).

Sayg1 değeri incelenen yazı türlerinde, bilge insanlara hürmet etmek, atalarımıza saygı duymak, yeryüzünde her şey Allah tarafından yaratıldığı için sayg1 duymak, topluma hizmet edenlere saygılı olmak, aile büyüklerine saygı göstermek olarak ele alınmıştır.

Nezaket değeri yazı türlerinden hikâyelerde $(f=10)$, masalda $(f=3)$ ve çizgi romanda $(\mathfrak{f}=14)$ defa yer almıştır. Nezaket değeri ile ilgili doğrudan alıntılara aşağıda yer verilmiştir:

"...Merhaba. Seninle tanıştığıma memnun oldum" (Ebru, Sayı 1, s.7).

"Maşallah Halil'im! Hastaneden çıktığın duyunca çocuklarla geçmiş olsun demeye

gelelim dedik. Nasılsın inşallah, iyi misin?"(Kadim Dede, Sayı 4, s.44).

Nezaket değeri incelenen yazı türlerinde, yapılan iş karşılığında teşekkür etmek, insanlarla selamlaşmak, hâl hatır sormak, hastalara geçmiş olsun demek, yapılan hata karşısında özür dilemek, insanlara karşı nazik olmak, hayvanları incitmemek boyutlarında yer verilmiştir.

Hoşgörü değeri yazı türlerinden yalnızca hikâyelerde $(\mathrm{f}=1)$ defa yer almıştır. Hoşgörü değeri ile ilgili doğrudan alıntılara aşağıda yer verilmiştir:

“Onun bu farklıliklarl, çevresinde daha çok sevilmesine neden olurmuş. Öyle ya, beş parmağın beşi bir değil. Farklılıklar hayatı renklendirir, tabiata neşe katar"(Kırk Yusuf, Sayı 1, s.11).

Hoşgörü değeri incelenen yazı türlerinde, farklılıkları sevmek, insanlar arasında ayrım yapmamak, insanları olduğu gibi kabul görmek üzerinde durulmuştur.

Alçak gönüllük değeri yazı türlerinden sadece hikâyede $(\mathfrak{f}=3)$ defa yer almaktadır. Alçak gönüllük değeri ile ilgili doğrudan alıntılara aşağıda yer verilmiştir:

"Annem kendisiyle dertleşmek için gelenleri dinlerken dertleriyle dertleniyor, onlarla seviniyor, hüzünleniyor, mutlu oluyordu. Onlara akıl veren, bilgiç bir tavırla değil, hayata onların baktı̆̆l yerden bakarak dinliyordu herkesi"(Dedemden Anneme Miras, Sayı 7, s.4).

"Ne zaman böbürlenecek olsan Neşet'i dinle, o sana toprak gibi olmayı öğretir derdi" (Dedemden Anneme Miras, Sayı 7, s.4).

Alçak gönüllük değeri incelenen yazı türlerinde, insanlardan kendini üstün görmemek, yaptığı işi küçümsemek olarak ele alınmıştır.

Vatanseverlik, Milli Birlik Bilinci, Özgürlük, Cesaret ve Kahramanlık Değerleri Vatanseverlik, milli birlik bilinci, özgürlük, cesaret ve kahramanlık değerlerinin dergilerde bulunan yazı türlerinde yer alma durumları, Tablo $4^{\prime}$ te verilmiştir. 
Tablo 4.

Vatanseverlik, Milli Birlik Bilinci, Özgürlük, Cesaret ve Kahramanlık ve Değerleri

\begin{tabular}{lcccc}
\hline & & Yazı Türleri & \\
\cline { 2 - 4 } Değerler & Hikâye & Masal & Çizgi Roman & Toplam \\
\hline Vatanseverlik & 6 & - & 11 & 17 \\
Milli Birlik Bilinci & - & - & 1 & 1 \\
Özgürlük & 6 & 1 & - & 7 \\
Cesaret & 2 & 2 & 2 & 6 \\
Kahramanlık & - & 1 & 3 & 4 \\
Toplam & 14 & 4 & 17 & 35 \\
\hline
\end{tabular}

Tablo 4'te yer alan vatanseverlik, milli birlik bilinci, özgürlük, cesaret ve kahramanlık değerine toplam $35 \mathrm{kez}$ yer verilmiştir. Bu grupta vatanseverlik ( $f=17)$ değerinin en fazla yer aldığı, sonrasında özgürlük $(f=7)$ değeri, cesaret $(f=6)$ değeri, kahramanlık $(\mathrm{f}=4)$ değeri ve milli birlik bilinci $(\mathrm{f}=1)$ değerinin takip ettiğ görülmektedir.

Vatanseverlik değeri yazı türlerinden hikâyede $(f=6)$ ve çizgi romanda $(f=11)$ defa yer almıştır. Vatanseverlik değeri ile ilgili doğrudan alıntılara aşağıda yer verilmiştir:

\footnotetext{
"...Zaten annem de anlatırken hep şöyle derdi "Biz en çok Türk semalarnnda kanat çırpmayı severdik. Çünkü oraların gö̆g̈ü alabildiğine turkuazdır, tıpkı kanatlarımız gibi"'(Kafesteki Turkuaz, Say1 4, s.9).

"...Aferin evlâdım. Bizlere yakışan, vatanımızla ve göğünde dalgalanan al bayrağımızla gurur duymak ve her daim onları korumaya çalışmaktır"(Kadim Dede, Say1 4, s.44).

"Aslında Anadolu'nun her köşesinde bir efsane, acılı bir şehit hikâyesi yok mu? Yavuklusunun özlemini duya duya bir sandık cephaneyi düşmana bırakmama uğruna arkadaşlarn ile ricat etmeyen genç şehidin memleket özlemi..."(Yellice'nin Üveyikleri, Sayı 5, s.40).
}

Vatanseverlik değeri incelenen yazı türlerinde, vatan için şehit olmak, vatan gazi olmak, vatan için fedakârlık yapmak, vatanını sevmek, vatanını kurtarmaya çalışmak, devletine karşı sorumluluğunu yerine getirmek, vatanını özlemek, vatanına kavuşunca mutlu olmak, vatanında yaşamayı istemek, vatanın birliğini korumak boyutlarında ele alınmıştır.

Milli birlik bilinci değeri yazı türlerinden yalnızca çizgi romanda ( $f=1$ ) defa yer almıştır. Milli birlik bilinci değeri ile ilgili doğrudan alıntılara aşağıda yer verilmiştir:

"Evet Ahmetciğim. Bu kutsal değerlerimiz ve vatanımızın elden gideceği korkusu bir an bile çıkmamıştı aklımdan. Vatan bizim hep birlikte yaşadığımız kocaman bir evdir" (Kadim Dede, Sayı 4, s.47).

Milli birlik bilinci değeri incelenen yazı türlerinde, birlik beraberlik içinde yaşamak, vatan için birlikte mücadele etmek olarak ele alınmıştır.

Özgürlük değeri yazı türlerinden hikâyede $(f=6)$ ve masalda $(f=1)$ defa yer almıştır. Özgürlük değeri ile ilgili doğrudan alıntılara aşağıda yer verilmiştir:

"Ben de özgürlüklerinden vazgeçmemelerini hatırlatmak için türkülerimle kardeşlerimin yaralarna merhem, gönüllerine umut olmaya gidiyorum" (Kafesteki Turkuaz, Sayı 4, s.11).

"Bir müddet bekledi Karanfil. Sonra içine bir cesaret geldi ve aniden havalandr. Evet, işte bu kadar kolaydı. Gökyüzünde özgürce uçmak inanılmazdı! Yeryüzünü yukarıdan izliyor ve gördüklerine inanamıyordu"( Karanfil, Sayı 1, s.23). 
Özgürlük değeri incelenen yazı türlerinde, özgür doğmak, vatanında özgürce hareket edebilmek, özgürlükten vazgeçmemek, tutsak yaşamanın zorluğu, özgür ruhlu olmak, esaretten kurtulmak, istediklerini yapabilmek şekilde ele alınmıştır.

Cesaret değeri yazı türlerinden hikâyede $(f=2)$, masalda $(f=2)$ ve çizgi romanda $(\mathrm{f}=3)$ defa yer almıştır. Cesaret değeri ile ilgili doğrudan alıntılara aşağıda yer verilmiştir:
"Annesi duyduklarının anlamını çok iyi biliyordu. Karanfil de arkadaşlarıla birlikte olmak istiyor ve babasını çok özlüyordu. Onun bu üzüntüsünün gittikçe arttığını gören annesi, çoktandır düşündüğ̈̈ ama bir türlü cesaret edemediği şeyi yapmaya karar verdi. Karanfil'i de alıp buralardan gidecek, diğer filleri bulacaklardı"(Karanfil, Sayi 1, s.25).

Cesaret değeri incelenen yazı türlerinde, sevdikleri için tehlikeye girmek, zorluklar karşısında kararlı olmak, vatan için canını feda etmekten çekinmemek, korkusuz olmak, ölümden korkmamak, korku duyulan davranışları denemek, düşmana firsat vermemek, korkmadan savaşmak olarak ele alınmıştır.

Kahramanlık değeri yazı türlerinden masalda $(f=1)$ ve çizgi romanda $(f=2)$ defa yer almıştır. Kahramanlık değeri ile ilgili doğrudan alıntılara aşağıda yer verilmiştir:

"Yıldız kurtulmuştu. Gökyüzünden, göz kırparak Baliş'e teşekkür etti. Baliş o günden sonra, yıldız kurtaran bir kahraman oldu"(Baliş'in Oyunları, Sayı 1, s.19).

"...Koş! diyor ," Koş hemen müdahale etsinler!" Kan kaybediyorsun kangren olursun, çabuk ol!"

-Yok diyor. Komutanım ben arkadaşlarımı, sizi burada bırakıp kendimi kurtarmaya koşamam"'(Kadim Dede, Sayı 5, s.35).

Kahramanlık değeri incelenen yazı türlerinde, birinin hayatını kurtarmak ve vatanı için savaşmak, mücadele etmek şeklinde ele alınmıştır.

\section{Paylaşmak, Fedakârlık, Yardımseverlik, Dayanışma ve Merhamet Değerleri}

Paylaşmak, fedakârlık, yardımseverlik, dayanışma ve merhamet değerlerinin dergilerde bulunan yazı türlerinde yer alma durumları, tablo $5^{\prime}$ te verilmiştir.

Tablo 5

Paylaşmak, Fedakârlık, Yardımseverlik, Dayanışma ve Merhamet Değerleri

\begin{tabular}{lcccc}
\hline & \multicolumn{3}{c}{ Yazı Türleri } & \\
\cline { 2 - 4 } Değerler & Hikâye & Masal & Çizgi Roman & Toplam \\
\hline Paylaşmak & 12 & 3 & - & 15 \\
Fedakârlık & 7 & - & 6 & 13 \\
Yardımlaşma & 4 & 4 & 2 & 10 \\
Dayanı̧ma & 3 & 1 & 1 & 5 \\
Merhamet & 2 & 1 & 1 & 4 \\
Toplam & 28 & 9 & 10 & 47 \\
\hline
\end{tabular}

Tablo 5'te yer alan paylaşmak, fedakârlık, yardımseverlik, dayanışma ve merhamet değerine toplam $48 \mathrm{kez}$ yer verilmiştir. Bu grupta paylaşmak $(\mathrm{f}=15)$ değerinin en fazla yer aldığı, sonrasında fedakârlık (13), yardımlaşma $(f=10)$, dayanışma $(\mathrm{f}=5)$ ve merhamet $(\mathrm{f}=4)$ değerinin takip ettiği görülmektedir.

Paylaşmak değerine yazı türlerinde hikâyede $(\mathrm{f}=12)$ ve masalda $(\mathrm{f}=3)$ defa yer almıştır. Paylaşmak değeri ile ilgili doğrudan alıntılara aşağıda yer verilmiştir: 
"Susardım; oyun oynarken çok susardım. O zaman da bir arkadaşımızın getirdiğ $i$ suyu hep birlikte paylaşır, içerdik" (Benim Babam Bisiklete Benziyor, Sayı 6, s.20).

"Rasim Efendi bahçede çeşit çeşit meyveler, sebzeler ve çiçekler yetiştiriyordu. Tabii bu meyve, sebze ve çiçekleri satmıyor, kasabanın fakirlerine ikram ediyordu"(Gül Bahçesi, Sayı 2, s.31).

Paylaşmak değeri incelenen yazı türlerinde, yiyeceği paylaşmak, emeğini insanlarla paylaşmak, problemlerini arkadaşla paylaşmak, mutluluğu paylaşmak, üzüntüyü paylaşmak, arkadaşlarla oyunları paylaşmak, sohbeti paylaşmak, ihtiyacı olana dağıtmak, bilgiyi paylaşmak, sadaka vermek boyutlarında ele alınmıştır.

Fedakârlık değeri yazı türlerinden hikâyede $(f=7)$ ve çizgi romanda $(f=6)$ defa yer almıştır. (Karanfil, Sayı 1, s.29).

"İnsanın böyle güçlü kuvvetli babasının olması da ne iyi bir şey..." diye düşünmüş.

"Varsin babast gülmesin, gür sesli olsun, işte beni sirtına alıp doktora yaya olarak karların içinde yürüyerek götürüyor ya, bu iyi bir şey." demiş Mehmet"(Mehmet'in Babası, Sayı 6, s.37).

Fedakârlık değeri incelenen yazı türlerinde, vatan için her şeyi feda edebilmek, bağımsızlık için fedakârlıklar yapmak, sevdiklerini korumak için fedakârlıklar yapmak, evladını korumak için sıkıntılara katlanmak, insanları mutlu etmek için çabalamak şeklinde ele alınmıştır.

Yardımlaşma değeri yazı türlerinden hikâyede $(\mathrm{f}=4)$, masalda $(\mathrm{f}=4)$ ve çizgi romanda $(f=2)$ defa yer almıştır. Yardımlaşma değeri ile ilgili doğrudan alıntılara aşağıda yer verilmiştir:

"Yıldızı, önce bir kuyruk darbesiyle suyun yüzüne çıkarttı. Ardından da güçlü bir nefesle, onu fişkırttı̆̆ı suyun önüne kâtip gökyüzündeki yerine gönderdi. Yıldız kurtulmuştu"(Baliş'in Oyunları, Sayı1, s.19).

"Rasim Efendi bahçede çeşit çeşit meyveler, sebzeler ve çiçekler yetiştiriyordu. Tabii bu meyve, sebze ve çiçekleri satmıyor, kasabanın fakirlerine ikram ediyordu. Çiçekleri ise daha çok evinde, bahçesinde yetiştirmek isteyen insanlara veriyordu" (Gül Bahçesi, Sayı 2, s.31).

Yardımseverlik değeri incelenen yazı türlerinde, insanlara problemlerini çözmek için yardım etmek, birine zarar gelmesini engellemek, amaca ulaşabilmek için yardım etmek, hayvanlara doğada rahat yaşamaları için yardımda bulunmak, büyüklere yardımcı olmak şeklinde ele alınmıştır.

Dayanışma değeri yazı türlerinden hikâyede $(\mathrm{f}=3)$, masalda $(\mathrm{f}=1)$ ve çizgi romanda $(f=1)$ defa yer almıştır. Dayanışma değeri ile ilgili doğrudan alıntılara aşağıda yer verilmiştir:

"...Benimle birlikte cihada gelmekte veya ayrilmakta serbestsiniz. Seninleyiz! Daima seninleyiz!"(Kadim Dede, Sayı 1, s.32).

"Dedem oturduğu yerden mızıkasını çalıyor, komşular da etrafinda toplanmış onu dinliyordu. Meğer kasabalı eş dost durumdan haberdar olup mızıkayı bizden önce alıvermişti" (Dedemin Kırmızı Mızıkası, Sayı 4, s.24).

"Bayan Çur Kağan Uygurların başına geçtiği zaman işlerin kâğıtsız yürümeyeceğini anladı. Hemen aksakall atalan, ak perçemli analan, şeşenleri, ozanlar toplayıp söz söyledi, söz dinledi. "Ellere muhtaç olmamak gerek." dedi. " Bir akıl verin bizim de kâğıdımız olsun." (Kâğıt İcadı Nasıl Oldu? Sayı 5, s.21-22).

Dayanışma değeri incelenen yazı türlerinde, yeni şeyler üretmek için birlik olmak, bir amaç için birlikte hareket etmek, yardımlaşma duygusunu canlı tutmak, iş birliği yapmak, başarı için ekip çalışması yapmak, vatanı kurtarmak için mücadele etmek boyutları ele alınmıştır. 
Merhamet değeri yazı türlerinden hikâyede $(f=2)$, masalda $(f=1)$ ve çizgi romanda $(f=1)$ defa yer almıştır. Merhamet değeri ile ilgili doğrudan alıntılara aşağıda yer verilmiştir:

"Benim merhametli Mehmetçik'im yaralı bir insana, düşmanı bile olsa zarar verebilir miydi? Kendini savunamayacak olan birine silah doğrultabilir miydi? "(Zeytin Ağacı, Sayı 3, s.42).

Merhamet değeri incelenen yazı türlerinde, insanlara karşı merhamet etmek, hayvanlara karşı merhamet etmek, savunmasız insana zarar vermemek, kötülüğün karşısında affedici olmak şeklinde ele alınmıştır.

\section{Ahlaklı Olma, Dürüstlük, Adil Olma ve Sorumluluk Sahibi Olma Değerleri}

Ahlaklı olma, dürüstlük, adil olma ve sorumluluk sahibi olma değerlerinin dergilerde bulunan yazı türlerinde yer alma durumları, tablo 6' de verilmiştir.

Tablo 6.

Ahlaklı Olma, Dürüstlük, Adil Olma ve Sorumluluk Sahibi Olma Değerleri

\begin{tabular}{lcccc}
\hline & \multicolumn{3}{c}{ Yazı Türleri } & \\
\cline { 2 - 4 } Değerler & Hikâye & Masal & Çizgi Roman & Toplam \\
\hline Ahlaklı Olma & 6 & 1 & - & 7 \\
Dürüstlük & 3 & 1 & 1 & 5 \\
Adil Olma & - & - & 1 & 1 \\
Sorumluluk Sahibi & 2 & - & - & 2 \\
Olma & & 2 & 2 & 15 \\
Toplam & 11 & & & \\
\hline
\end{tabular}

Tablo 6'da yer alan ahlaklı olma, dürüstlük, adil olma ve sorumluluk sahibi olma değerine toplam $15 \mathrm{kez}$ yer verilmiştir. Bu grupta ahlaklı olma $(\mathfrak{f}=7)$ değeri en fazla yer aldığı sonrasında dürüstlük $(\mathrm{f}=5)$ değeri ve sorumluluk sahibi olma (f=2) değeri ve adil olma ( $f=1)$ değeri gelmektedir.

Ahlaklı olma değeri yazı türlerinden hikâyede $(f=6)$ ve masalda $(f=1)$ defa yer almıştır. Ahlaklı olma değeri ile ilgili doğrudan alıntılara aşağıda yer verilmiştir:

"Ahmed Yesevi geçimini sağlamak için tahtadan kaşık ve kepçeler yapardı. Bu işin pîri yani öncüsü oydu. Çünkü o, kişinin mesleğini yaparak, alın teri ile para kazanmasına önem verir; öğrencilerini meslek sahibi olmaları için yönlendirir, kendi sanatını onlara da öğretirdi" (Tüccar Öküz, Sayı 3, s.23).

"Bir kişi arkadaşının tarlasında çalışıyordu. Öylesine emek veriyordu ki sonunda bir küp altın buldu. Alıp arkadaşına götürdü: "Talih sana güldü, tarlanda hazine buldum, al kardeşim" dedi. Arkadaşı çok duygulandı: "Sen ne yüce gönüllü bir arkadaşsın Ahmet," diye cevap verdi. "O senin hakkın, çalıştın, ter döktün, karşılığını buldun, al götür" (Hakan Şenbek, Sayı 3, s.32).

Ahlaklı olma değeri incelenen yazı türlerinde, haklı kazanç elde etmek, herkese hakkını vermek, hak yememek, ahlakı gönüllerde aramak, insanlara ahlakına, iyilik yapmaya önem vermek göre değer vermek boyutlarına yer verilmiştir.

Dürüstlük değeri yazı türlerinden hikâyede $(\mathrm{f}=3)$, masalda $(\mathrm{f}=1)$ ve çizgi romanlarda $(\mathrm{f}=1)$ defa yer almıştır. Dürüstlük değeri ile ilgili doğrudan alıntılara aşağıda yer verilmiştir:

"Kırk Yusuf, insanların diş görünüşlerine değil, dürüstlüklerine ve ahlaklarına önem verirmiş" (Kırk Yusuf, Sayı 1, s.10). 
Dürüstlük değeri incelenen yazı türlerinde, insanların dürüstlüklerine göre değer vermek, söylemek istenilenleri direk söylemek, dürüstlük ile insanların güvenlerini kazanmak, her koşulda doğru olmak, yalan söylememek şeklindedir.

Adil olma değeri yazı türlerinden yalnızca çizgi romanda $(f=1)$ defa yer almıştır. Adil olma değeri ile ilgili doğrudan alıntılara aşağıda yer verilmiştir:

"Batıya doğru genişleyecek ve üç kıtaya hükmedecek olan devletini evlatlarn ve torunların adaletle yönetecekler"(Kadim Dede, Sayı 2, s.34).

Adil olma değeri incelenen yazı türlerinde devleti adil yönetmek anlamında ele alınmıştır.

Sorumluluk değeri yazı türlerinden yalnızca hikâyede $(\mathrm{f}=2)$ defa yer almıştır. Sorumluluk değeri ile ilgili doğrudan alıntılara aşağıda yer verilmiştir:

"Böyle düşünürken beni uyardı. "Ama ödevini ben yapamam, sen yaparsin. Ben

belki sana ilham veririm. Bu senin vazifen, unutma!"(Dedemden Anneme En

Güzel Miras, Sayı 7, s. 5).

Sorumluluk değeri incelenen yazı türlerinde, kendine ait görevlerin farkına varmak ve aile bireylerin ihtiyaçlarını karşılamak olarak ele alınmıştır.

\section{Sağlık ve Temizlik Değerleri}

Sağlık ve temizlik değerlerinin dergilerde bulunan yazı türlerinde yer alma durumları, tablo 7'de verilmiştir.

Tablo 7

Sağlık ve Temizlik Değerleri

\begin{tabular}{lcccc}
\hline & \multicolumn{3}{c}{ Yazı Türleri } & Toplam \\
\cline { 2 - 4 } Değerler & Hikâye & Masal & Çizgi Roman & 1 \\
\hline Sağlik & 1 & - & - & 1 \\
Temizlik & 1 & - & - & 2 \\
Toplam & 2 & - & - & 2 \\
\hline
\end{tabular}

Tablo 7' de yer alan sağlık ve temizlik değerine toplam 2 kez yer verilmiştir. Bu grupta sağllk $(\mathfrak{f}=1)$ değeri ve temizlik $(\mathrm{f}=1)$ değeri eşit verildiği görülmektedir.

Sağlık değeri ve temizlik değeri yazı türlerinden hikâyede $(f=2)$ yer almıştır. Sağlık değeri ile ilgili doğrudan alıntılara aşağıda yer verilmiştir:

"Odadaki çocukların hepsi dişlerini her gün firçalayacă̆ına, sütünü her gece düzenli içeceğine ve hatta artık ıspanak yerken mızıkçılık yapmayacă̆ına dair sözler vermişti"(Dedemin Kırmızı Mızıkası, Sayı 4, s.24).

\section{Tek tek ele alınan (Mutluluk ve Sabır) Değerler}

Mutluluk ve sabır değerlerinin dergilerde bulunan yazı türlerinde yer alma durumları, Tablo 8' de verilmiştir.

Tablo 8

Tek tek ele alınan ( Mutluluk ve Sabır) Değerler

\begin{tabular}{lcccc}
\hline & \multicolumn{3}{c}{ Yazı Türleri } & Toplam \\
\cline { 2 - 4 } Değerler & Hikâye & Masal & Çizgi Roman & Tom \\
\hline Mutluluk & 6 & 3 & 2 & 11 \\
Sabır & - & - & 1 & 1 \\
Toplam & 6 & 3 & 3 & 12 \\
\hline
\end{tabular}


Tablo 8' de yer alan mutluluk ve sabır değerine toplam 12 kez yer verilmiştir. $\mathrm{Bu}$ grupta en fazla mutluluk $(\mathrm{f}=11)$ değerinin yer aldığı sonrasında $\operatorname{sabır}(\mathrm{f}=1)$ değerinin takip ettiği görülmektedir.

Mutluluk değeri yazı türlerinden hikâyede $(\mathrm{f}=6)$, masalda $(\mathrm{f}=3)$ ve çizgi romanlarda $(\mathrm{f}=2)$ defa yer almıştır. Mutluluk değeri ile ilgili doğrudan alıntılara aşağıda yer verilmiştir:

"Mutluluktan nereye gittiklerini bile unutmuş, saatlerce güle oynaya şarkılar söylemişlerdi. Derken Karanfil son şarkısını da söyleyip sustu. Hepsi birden neden sustun dediler"( Karanfil, Say1 1, s.24).

"...Hatta televizyondaki yarışmalan bile takip etmeye başladı. Biz yapacak iş bulduk ya çok mutluyduk"(Artık Canımız Sıkılmıyor, Sayı 2, s.48).

"Babama doğru koştum. "Babaaaaa, bana bisiklet mi aldın?" diye sevinçle bağırarak sordum"(Benim Babam Bisiklete Benziyor, Sayı 6, s.20) .

Mutluluk değeri incelenen yazı türlerinde, arkadaşlarla birlikte olmak, sevdikleriyle bir şeyler paylaşmak, sağlıklı olmak, hediye almak, insanlara yardım etmek şeklinde ele alınmıştır.

Sabır değeri yazı türlerinden yalnızca çizgi romanda $(\mathrm{f}=1)$ defa yer almıştır. Sabır değeri ile ilgili doğrudan alıntılara aşağıda yer verilmiştir:

“Öfke afet gibidir oğul. İnsanoğlu dağları devirir ama öfkesine yenilir. Daima sabırlı

ol"(Kadim Dede, Sayı 2, s.34).

Sabır değeri incelenen yazı türlerinde öfkeye hâkim olmak olarak ele alınmıştır.

\section{Tartışma, Sonuç ve Öneriler}

Araştırmada AÇSHB tarafından yayınlanan "Sevgi Bir Kuş" isimli çocuk dergisinin 2015-2020 yılları arasında basılan 7 sayısı incelenmiştir. Bu dergi serisinde yer alan hikâye, masal ve çizgi roman edebi türlerinde işlenen değerler tespit edilmiştir. Analiz sonucunda dergilerde yer alan 32 edebi türde 29 farklı değerin, 226 defa yer aldı̆̆ 1 tespit edilmiştir. Araştırmada en çok yer verilen değerlerin sevgi, nezaket, vatanseverlik ve paylaşmak olduğu en az yer verilen değerlerin barış, hoşgörü, milli birlik, adil olma, sağlık, temizlik ve sabır olduğu görülmüştür. Değerlerin en çok sirasılyla hikâye $(f=129)$, çizgi roman $(f=64)$ ve masal $(f=33)$ edebi türlerinde geçtiği görülmektedir. Araştırma sonuçlarına bakıldığında değerlerin dergide yer alan edebi türlerden en çok hikâye ve çizgi roman ile öğretildiği dikkat çekmektedir. Gurbetoğlu (2007) tarafından “II. Meşrutiyet Dönemi Çocuk Dergileri” çalışmasında değerlerin daha çok hikâye ve masal aracılığıyla öğretildiği bu noktada çalışmamızdan farklılaştığı tespit edilmiştir. Bu durum çocuk dergilerinde yer alan edebi türlerden hikayeye daha çok yer verilmesinden kaynaklandığı düşünülebilir.

Ortaya çıkan değerlerin Schwartz'in (1996) belirlemiş olduğu değerler; UNESCO'nun evrensel değerleri (UNESCO, 2020 ) ve Milli Eğitim Bakanlığı'nın öğretim programlarında (MEB, 2020) yer verilen değerler ile örtüştüğü tespit edilmiştir.

$\mathrm{Bu}$ araştırmada yer alan edebi türlerde en çok işlenen değer sevgi değeridir. Alabay ve diğerleri (2018) Meraklı Minik çocuk dergisini UNESCO'nun 12 evrensel değeri açısından inceledikleri araştırmada "sevgi" değerinin en yoğun işlenen değer olduğunu tespit etmişlerdir. Dirican ve Dağlıoğlu (2013) tarafından 3-6 yaş çocuk kitapları üzerine yapılan incelemede de en çok yer alan değerin sevgi değeri olduğu gözlemlenmiştir. Şen (2007) araştırmasında yerli ve yabancı yazarlara ait 100 Temel 
Eser'de sevgi değerinin en çok işlendiği görülmektedir. Özbay ve Tayşi (2011) tarafından yapılan araştırmada Dede Korkut Hikâyelerinde sevginin insanların birlikte yaşayabilmesi için önemi üzerinde durarak sevgi değerinin diğer değerlere göre daha çok yer aldığı görülmektedir. Karagöz (2018), Emin Özdemir'in çocuk kitaplarına yönelik çalışmasında "Sevgi bir güçtür" ifadesiyle çalışmada en çok yer alan sevgi değerinin önemini açıkça ifade etmiştir. Literatürde çocuklara yönelik hazırlanan eserlerin incelendiği araştırmalarda bu araştırmada olduğu gibi sevgi değerinin diğer değerlere göre daha ön planda olduğu görülmektedir. Bunun nedeni yazarların çocuklara sevgi değerinin verilmesini daha öncelikli olarak görmesi ya da bu değeri daha kolay aktarabilmesinden kaynaklı olabilir. Ayrıca sevgi değerinin anlam ve içeriğinin de geniş olması bu değerin edebi yazında daha fazla yer verilmesine sebep olabilir. Örneğin sevgi değeri; hayvan sevgisi, doğa sevgisi gibi farklılaşabildiği gibi, vatanseverlik değerinde vatan sevgisi, yardımlaşma değerinde insana olan sevgi, aile birliğine önem verme de aile bireylerine olan sevgi şeklinde temel de yatan bir değer olarak düşünülebilir. Bu nedenle sevgi değerinin diğer değerler açısından bir temel oluşturduğu varsayılabilir. Bireylerin toplumda yaşayabilmeleri için fizyolojik ihtiyaçlardan sonra en önemli ihtiyaçları sevmek ve sevilmektir (Güler, 2014, s.74). Maslow'un ihtiyaçlar hiyerarşisinde de bireylerin fiziksel ve güvenlik ihtiyaçlarından sonra sevgi, sevilme ve bir yerlere aitlik ihtiyaçlarının giderilmesi gerekmektedir (McLeod, 2007). Çocuklara öğretim sırasında bu değerin daha çok ön planda olması diğer değerlerin daha kolay benimsetilmesinde destekleyici olacağı düşülmektedir (Candan ve Ergen, 2014, s.155). Dolayısıyla incelenen edebi türlerde de sevgi değerine sıklıkla yer verilmesi diğer değerlerin benimsetilmesi açısından önem arz etmektedir.

Sevgi değerinden sonra en çok yer alan değerlerin sırasıyla nezaket, vatanseverlik, paylaşmak ve yardımlaşma olduğu görülmektedir. Turan ve Ulutaş (2016) resimli öykü kitaplarına yönelik çalışmada yerli ve yabancı öykülerde işlenen değerler arasında nezaket değerinin en çok yer alan değerlerden olmaması nedeniyle bu araştırmanın sonuçlarıyla örtüşmemektedir. Cengiz ve Duran (2017) hikâye ve masal kitaplarına yönelik değerleri incelediğinde mutluluk değerinden sonra en fazla nezaket değerinin yer aldığ1 sonucuna ulaşmıştır. Dirican (2013)' in 3-6 yaş çocuklarına yönelik resimli hikâye kitaplarında yaptığı çalışmada hikâyelerin metin kısımlarında olduğu gibi nezaket değerine çok sık rastlanmıştır. Nezaket değerinin edebi türlerde sıkılıkla kullanılması, nezaket ifadelerinin yetişkinlerin farkında olmadan günlük yaşamda çok sık kullanmasından kaynaklanabilir. Bu araştırmada edebi türlerde geçen nezaket sözcükleri günlük yaşamda "teşekkür etmek, selamlaşmak, özür dilemek" gibi yaşanan olaya göre kullanılan ifadeler olduğu görülmektedir. Yavuzer (2001)'e göre çocuğun kişiliğinin temelleri atılırken özdeşleşebileceği bir modele ihtiyaç duyar. İlk zamanlarda bu model çocuğun ebeveynleri ve akrabalarıyken, bir süre sonra arkadaşları, izledikleri bir film ya da okudukları kitaptaki kahramanlar olur. Edebi türlerde geçen kahramanların nezaket kurallarına uyması çocukların doğru rol model alabilmeleri açısından önemli bir etkisi olduğu düşünülebilir.

Eker ve Yıldırım (2017) 100 Temel Eser' de yer alan Ziya Gökalp'in “Altın Işık” isimli kitabında vatanseverlik değeri, bu araştırmanın bulgularındaki benzer şekilde en çok yer alan değerlerden biri olmuştur. Kılcan ve Üçarkuş (2018) Eğitim Bilişim A ğ1 (EBA) dergilerini değerler eğitimi açısından inceledikleri çalışmalarında, sosyal 
bilgiler 6 ve 7 . sınıf öğretim programında yer alan ve öğrencilere kazandırılması hedeflenen 13 değer arasından en çok işlenen değerler arasında vatanseverlik değerinin olması bu araştırmanın sonuçlarını desteklemektedir. Turan ve Ulutaş'ın (2016) resimli öykü kitaplarına, Cengiz ve Duran'ın (2017) hikâye ve masal kitaplarına yönelik değerler çalışmalarında ayrıca Yılmaz ve Duman'ın (2018) “TRT Çocuk Dergisi'nde Milli Bir Değer Olarak “Vatan - Vatanseverlik” Değeri” çalışmasında vatanseverlik değerinin bu araştırmanın bulgularının aksine en az işlenen değerler arasında olması nedeniyle bu araştırmanın sonuçlarıyla benzerlik göstermemektedir. Bireyler farkına varmadan diğerinin önüne geçme ve var olma çabası içinde yerel ve milli değerlerini unutmaktadır. Bu sorun özellikle henüz değerleri yeni gelişmekte olan çocuk ve gençleri olumsuz yönde etkilemektedir (Demir, 2018). Küçük yaşlardan itibaren vatan sevgisiyle büyüyen bir çocuğun, yetişkinlikte vatanına faydalı olabilmek için daha çok çalıştığı, vatanına karşı sorumluluklarını bildiği düşünüldüğünde vatanseverlik değerinin incelenen edebi türlerde sıklıkla yer alması oldukça önemlidir. Dirican ve Dağlıŏlu (2014) tarafında 3-6 yaş çocuk kitapları üzerine yapılan incelemede paylaşmak değerinin bu araştırmada olduğu gibi ön planda olduğu görülmektedir. Tuğrul ve Feyman (2006) tarafından incelenen öykü kitaplarında en fazla paylaşmak ve yardımlaşmak değeri üzerinde durulmuş olup sık kullanıldığı görülmektedir. Paylaşma davranışını çocukların kendi kendilerine öğrenmeleri zordur. Bu nedenle çocuklara birebir fırsatlar tanınarak ya da doğru rol modellerle bir araya gelmelerini sağlayarak bu değerin kazandırılması için sık sık kullanıldığı ortamlar oluşturulabilir. Bu araştırmada olduğu gibi olduğu gibi çocukların okudukları hikâye, masal gibi türlerde bu değerin belirli ölçüde yer alması çocuğun daha kolay benimsemesini sağlayacaktır.

Araştırmada barış, hoşgörü, milli birlik, adil olma, sağlık, temizlik ve sabır değerleri en az işlenen değerlerdir. Eker ve Yıldırım (2017) 100 Temel Eser' de yer alan Ziya Gökalp'in "Altın Işık" isimli kitabında araştırmasında sabır değeri, Cengiz ve Duran'ın (2017) hikâye ve masal kitaplarına yönelik değerler çalışmasında barış değeri, Turan ve Ulutaş'ın (2016) resimli öykü kitaplarına yönelik çalışmasının sonuçlarında adil olma değeri, Güven'in (2004) Türk efsanelerinin değerler açısından incelenmesi araştırmasında temizlik değeri en az işlenen değerler arasındadır. Bu araştırmada az yer alan değerlerin literatürde ki araştırmalarda da az değinilen değerler arasında olduğu görülmektedir. Yukarıda bahsedilen değerlerin mümkünse birbirleri arasında ayrım yapılmadan ve eşit önem verilerek çocuklara kazandırılması gerekmektedir. Bu araştırmada da olduğu gibi edebi türlerde az yer alan değerlerin yok olmaması için daha çok işlenmesi gerekmektedir. Ayrıca barış, hoşgörü, milli birlik, adil olma, sağlık, temizlik ve sabır değerlerinin az olmasının sebebi bu değerlerin yazarlar tarafından edebi türlerde daha zor işlenmesinden veya örneklendirilmesinden kaynaklanabileceği düşünülmektedir.

"Sevgi Bir Kuş" isimli derginin özellikle AÇSHB'ye bağlı çocukların korunma altında bulunduğu kurumlarda okunduğu düşünüldüğünde en başta koruma altındaki çocuklara araştırmada ortaya koyulan değerlerin kazandırılması açısından önemli bir katkı sağlayacağı düşünülmektedir. Son olarak, "Sevgi Bir Kuş" dergisinde daha az yer verilen barış, hoşgörü, milli birlik, adil olma, sağlık, temizlik ve sabır değerleri değerlerine yer verilme sıkılığının arttırılması, görsel içeriği de bulunan çizgi romanlarda daha fazla değere yer verilmesi ve bu değerlerin görsellerle desteklenmesi 
dergiye değerlerin aktarımı açısından katkı sağlayacaktır. Ayrıca dergi içerik olarak masallar yönünden güçlendirilmeli ve çocuklara değer öğretiminde hikâye, masal ve çizgi roman dışında fıkra, şiir gibi edebi türlerinde etkili olduğu dikkate alınarak farklı edebi türlere yer verilmeli ve bu türler değerler açısından da güçlendirilmelidirler. Değerler farklı edebi türler kullanılarak belirli bir plan ve program çerçevesinde hazırlanabilir. Derginin her sayısında farklı bir değer/değerler teması belirlenerek değerler öğretilebilir. Ayrıca dergideki edebi türlerin olumlu ve olumsuz içerik açısından incelenmesi, dergide yer alan görsellerin çocuklara uygunluğu açısından incelenmesi, dergide yer alan edebi türlerdeki milli ve dini unsur ve ögelerin incelenmesi araştırmacılara önerilebilir.

\section{Kaynakça}

AÇSHB, (2020a). Sevgi Bir Kuş Dergisi. https:/ / sevgibirkus.com.tr 14.06.2020 tarihinde erişildi.

AÇSHB, (2020b). Aile ve Sosyal Politikalar alanındaki çocuk istatistikleri. https:/ / www.ailevecalisma.gov.tr/tr-tr/istatistikler/aile-ve-sosyalpolitikalar-alanindaki-istatistikler/cocuk-hizmetleri-istatistikleri/ 13.06.2020 tarihinde erişildi.

Alabay, E., Can, B. H., Kandemir, A. B. ve Güney, K. (2018). TÜBİTAK tarafından yayınlanan Meraklı Minik çocuk dergisinin değerler açısından incelenmesi. Değerler Ĕ̈itimi Dergisi, 16(35), 7-26.

Alabaş, R. ve Kamer, S. T. (2016). Afacan Çocuk Gözü dergisi ve çocuğun vatandaş olarak eğitimi. Turkish Studies-International Periodical for the Languages, Literature and History of Turkish or Turkic, 11(3), 77-92. doi:http://dx.doi.org/10.7827/TurkishStudies.9273

Akbayrak, K. (2014). Erken cumhuriyet döneminde sosyalleşme aracı olarak süreli çocuk yayınları (mektepli gazetesi, çocuk, çocuk sesi dergileri örneği). Ankara Üniversitesi, Eğitim Bilimleri Enstitüsü, Yüksek Lisans Tezi, Ankara, (366569).

Uyanık Balat, G. (2012). Okul öncesinde değerler eğitimi. İçinde G. Balat Uyanık(Ed), okul öncesinde değerler eğitimi ve etkinlik örnekleri (ss.2-33). Ankara: Pegem Akademi Yayınları.

Balc1, A. (2017). “Çocuklara Rehber” dergisinin kütüphane kataloglarında görülmeyen 168, 16 ve 173. sayılarının incelenmesi. Uluslararası Türkçe Edebiyat Kültür Ĕ̆itim Dergisi, 6(2), 986-1001. https:/ / doi.org/10.7884/teke.3830

Bolat, Y. (2016). Sosyal değerleri ve değerler eğitimini anlamak. Akademik sosyal araştırmalar dergisi, 4(29), 322-348. https://doi.org/10.16992/ASOS.1283

Cengiz, Ş. ve Duran, E. (2017). Okul öncesi dönemine ait hikâye ve masallardaki değerlerin incelenmesi. Eğitim ve Bilim Dergisi, 42(191), 205-233. doi: http://dx.doi.org/10.15390/EB.2017.6945

Candan, D. G. ve Ergen, G. (2014). 3. sınıf hayat bilgisi ders kitaplarının temel evrensel değerleri içermesi bakımından incelenmesi. Uşak Üniversitesi Sosyal Bilimler Dergisi, 7(1), 134-161.

Chick, K. A. and Hunter, M. W. (2009). An analysis of human images and advertisements. Language and Literacy, 11(1),1-25. doi: https:/ / doi.org/10.20360/G25P4F 
Çengelci, T.ve Eryılmaz, Ö. (2018). Sosyal bilgilerde edebi ürünler ve değerler eğitimi: küçük prens örneği. Batı Anadolu Eğitim Bilimleri Dergisi, 9 (1), 65-79.

Çelikpazu, E. E. ve Aktaş, E. (2011). MEB 6, 7 ve 8. sınıf Türkçe ders kitaplarında yer alan metinlerin değer iletimi açısından incelenmesi. Electronic Turkish Studies, $6(2), 413-424$.

Grenby, M. O. and Reynolds, K. (2011). Children's literature studies: A research handbook. Macmillan International Higher Education.

Demir, E. (2018). Öğretmen adaylarının öğretmenlik mesleği ile ilgili değger algıları ve bu değerlerin eğitim fakültelerinde kazandırılmasına ilişkin görüşleri. Ankara Üniversitesi, Eğitim Bilimleri Enstitüsü, Doktora Tezi, Ankara, (524700).

Demir, T. (2012). İlköğretim sekizinci sınıf Türkçe ders kitaplarındaki hikâye metinlerinde yer alan değer unsurlarının eşdizimsel örüntülemeler açısından görünümleri. Electronic Turkish Studies, 7(2).

Demirtaş, S. (2009). Çocuk yuvasında kalan korunmaya muhtaç çocukların değer eğitiminde yaratıcı drama etkililiği (Yayınlanmamış Doktora Tezi). Hacettepe Üniversitesi, Ankara.

Dirican, R. ve Dağlıŏlu, H. E. (2013). 3-6 Yaş grubu çocuklarına yönelik yayımlanan resimli hikâye kitaplarının bazı temel değerler açısından incelenmesi (Yayımlanmamış Yüksek Lisans Tezi). Gazi Üniversitesi, Ankara.

Doğanay, A. (2006). Değerler eğitimi. Cemil Öztürk (Ed.). Hayat Bilgisi ve Sosyal Bilgiler Öğretimi Yapılandırmacı Bir Yaklaşım, (2. Baskı). (s. 255-286). Ankara: Pegem A Yayıncilik.

Eker, C. ve Yıldırım, K. (2017). Değerler eğitimi açısından Ziya Gökalp’e ait “Altın Işı" adlı eserin incelenmesi. Karaelmas Ĕ̆itim Bilimleri Dergisi, 5(1), 30-38.

Emek, M.(2010).Yenileşme dönemi Türk hikayeciliğinde öğretmen konulu hikâyelerde değer eğitimi(Yüksek Lisans Tezi). İnönü Üniversitesi, Malatya

Erdal, K. (2016). Keloğlan Masallarında Çocukların Eğitimine Yönelik İletiler. Uluslararası Türkçe Edebiyat Kültür Eğitim Dergisi, 5(4), s. 1805-1822. https:// doi.org/10.7884/teke.3767

Güçlü, M. (2015, Nisan). Türkiye'de değerler eğitimi konusunda yapılan araştırmalar. Eğitimde Gelecek Arayışları: Dünden Bugüne Türkiye' de Beceri, Ahlak ve Değerler Eğitimi Uluslararası Sempozyumu Bildirileri, Bartın. https:/ / doi.org/10.17719/jisr.20153813681

Gündoğdu, A. (2010). Değerlerle yaşamak. Eğitime Bakış Dergisi, 6(18), 1-3.

Güven, A. (2014). Türk efsanelerinin değerler eğitimi bakımından incelenmesi. Mustafa Kemal Üniversitesi Sosyal Bilimler Enstitüsü Dergisi, 11(26), 225-246.

Gezmen, B. (2019). Bir eğitim aracı olarak çocuk dergileri: “Mavi Kırlangıç” çocuk dergisi. Erciyes İletişim Dergisi, 6(1), 59-80.

https:/ / doi.org/10.17680/erciyesiletisim.466195

Gurbetoğlu, A. (2007). II. meşrutiyet dönemi çocuk dergilerinde ahlak eğitimi ve ahlaki değerler (1908-1918). Yüzüncü Yıl Üniversitesi Eğitim Fakültesi Dergisi, 4(1), 81-101.

Gönenç, M. E. (2005, Nisan). Çocuklara ve gençlere olumlu ahlaki ve insani değerlerin kazandırılmasında edebî metinlerin rolü ve önemi. Eğitimde Gelecek Arayışları: Dünden Bugüne Türkiye' de Beceri, Ahlak ve Değerler Eğitimi Uluslararası Sempozyumu Bildirileri, Bartın. 
Halstead, J. M. and Taylor, M. J. (2000). Learning and teaching about values: A review of recent research. Cambridge Journal of Education, 30(2), 169-202, s.169. doi:10.1080/713657146.

Hökelekli, H. (2010). Modern Eğitimde yeni bir paradigma: Değerler eğitimi. Eğitime Bakış Dergisi, 6(18), 4-9.

Karagöz, B. (2018). Emin Özdemir'in çocuk kitaplarına değerler eğitimi bağlamında bir bakış: Bir çözümleme çalışması. Pamukkale Üniversitesi Sosyal Bilimler Enstitüsü Dergisi, (31), 63-85. https:/ / doi.org/10.30794/pausbed.414620

Karatay, H. (2007). Dil edinimi ve değer öğretimi sürecinde masalın önemi ve işlevi. Türk Ĕ̈itim Bilimleri Dergisi, 5(3), 463-477.

Kılıç, A. ve Aktan O. (2015). İlköğretim okulları için tavsiye edilen 100 temel eserde vurgulanan değerler. Illköğretim Online, 14(1), 243-275, 2015. doi: 10.17051/io.2015.45177

Kılcan, B. ve Üçarkuş, E. (2018). Eğitim Bilişim Ağ1 (EBA) Dergilerinin Değerler Eğitimi Açısından İncelenmesi. Uluslararası Sosyal Bilgilerde Yeni Yaklaşımlar Dergisi (IJONASS), 2(1), 42-54.

Kaymakcan, R. (2010). Değer kavramı ve gençlerin dini değerleri. Eğitime Bakış Dergisi, 6(18), 10-15.

McLeod, S. (2007). Maslow's hierarchy of needs. Simply psychology, 1, 1-8.

Milli Eğitim Bakanlığı (MEB,2020). Öğretim Programları, http:/ / mufredat.meb.gov.tr/Programlar.aspx Erişim: 15.06.2020

Miles, M. B., and Huberman, A. M. (1994). Qualitative data analysis: an expanded sourcebook. California: Sage.

Oğuzkan, F. (2001). Çocuk edebiyatı. Ankara: Anı Yayıncılık.

Özbay, M. ve Karakuş, E. (2011). Dede korkut hikâyeleri'nin Türkçe öğretimi ve değer aktarımı açısından önemi. Pegem Ĕ̆itim ve Öğretim Dergisi, 1(1), 21-31. https:// doi.org/10.14527/C1S1M3

Özdaş, S. P. (2018). Muzaffer İzgü'nün Ökkeş Adlı Roman Serisinin Değerler Eğitimi ile Şekil ve İçerik Özellikleri Açısından İncelenmesi. Akra Kültür Sanat ve Edebiyat Dergisi, 6(15), 193-228. https:/ / doi.org/10.31126/akrajournal.412751

Sever, E., Memiş, A., Sever, S. (2015). Pertev Naili Boratav'ın Zaman Zaman İçinde Masal Kitabının Değerler Açısından İncelenmesi. Bartın Üniversitesi Eğitim Fakültesi Dergisi, XIV. Uluslararası Katılımlı Sınf Öğretmenliği Ĕ̆itimi Sempozyumu (21-23 Mayıs 2015), Özel Sayısı, s. 246 - 263. https:// doi.org/10.14686/BUEFAD.2015USOSOzelsayi13214

Schwartz, S. (1996). Value priorities and behavior: applying a theory of integrated value systems psicodebate. Psicología, Culturay Sociedad, 119-144.

Tökel, D. A. (2005). Eskilerde çocuk eğitimi: Çocuk edebiyatı gözüyle eskiye bakmak. Hece Dergisi Çocuk Edebiyatı Özel Sayısı, 104-105, 76-88.

Tuğrul, B. ve Feyman, N. (2006, Ekim). Okul öncesi çocuklar için hazırlanmış resimli öykü kitaplarında kullanılan temalar. II. Ulusal Çocuk ve Gençlik Edebiyatı Sempozyumu, Ankara.

Turan, F. ve Ulutaş, İ. (2016). Okul öncesi eğitim kurumlarındaki resimli öykü kitaplarının özellikleri ile öğretmenlerin bu kitapları kullanma durumlarının incelenmesi. The Journal of Educational Research, 2(1), 21-45.

UNESCO (2020). Reflection Points Posters. http:/ / www.livingvalues.net/posters Erişim Tarihi: 15.06 .2020 
Yiğittir, S. (2012). İlköğretim 5. sınıf öğrencilerinin değer yönelimlerinin Rokeach ve Schwartz değer sınıflandırmasına göre değerlendirilmesi. Dicle Üniversitesi Ziya Gökalp Eğitim Fakültesi Dergisi, (19), 1-15.

Yazıcı, K. (2006). Değerler eğitimine genel bakış. Türklük Bilimi Araştırmaları, (19), 499-522.

Yıldırım A. ve Şimşek H. (2018). Sosyal bilimlerde nitel araştırma yöntemleri. Ankara: Seçkin Yayıncılık.

Yılmaz, M. ve Duman, T. (2018). TRT Çocuk Dergisi'nde Milli Bir Değer Olarak "Vatan - Vatanseverlik" Değeri. Insan ve Toplum Bilimleri Araştırmaları Dergisi, 7(2), 639-657. https:// doi.org/10.15869/itobiad.394045

\section{Summary}

\section{Introduction}

People are not born with values. Values are phenomena learned later (Aydin, 2010, p.16). Values need to be passed on to future generations in order to maintain social peace. These transferred values are expected to be transformed into behaviours by children and youth. Therefore, it is necessary to start values education for children at an early age (Güçlü, 2015, p.33).

According to Tökel (2005), literature is one of the most important tools used in child education. Introducing children and young people into literary texts is one of the most effective methods. Children's magazines are one of them. They are important materials to contribute to children's development, education and training, selfexploration and adaption to the society (Oğuzkan, 2001; Aytaş and Yalçın, 2005; Kıbrıs, 2006 cited in Demiryürek, 2012).

In the children's magazine called "Sevgi Bir Kuş", there are informative texts about the history of our country, important people in our history, historical regions and geographical features, poems and short stories that children send to the magazine, games that support cognitive development for children and literary genres such as stories, folk tales, comics. There are auditory and visual varieties for the hearing and visually impaired children and children with special needs to benefit from the magazine (www.sevgibirkus.com.tr).

\section{Purpose}

The purpose of the current study is to determine the values in the literary genres of stories, folk tales and comics in the children's magazine "Sevgi Bir Kuş" issued by the Ministry of Family, Labour and Social Services.

\section{Method}

In this qualitative study, the document analysis method was used to determine the values in the literary genres of stories, folk tales and comics in the children's magazine "Sevgi Bir Kuş" issued by the Ministry of Family, Labour and Social Services. Document analysis refers to the analysis of written and visual materials including information about the phenomenon or phenomena under study (Yildırım and Şimşek, 2018 p. 189). 
The first issue of the magazine was published in 2015 and is published at certain intervals every year. From 2015 to 2020, 7 issues of the magazine were published. When the types of genres in all the magazines were examined, 17 stories, 6 folk tales and 9 comics were included in the study.

\section{Findings}

In the magazines, a total of 17 stories, 6 folk tales and 9 comics were examined. As a result, a total of 29 values obtained in 32 types of texts. These 29 different values were found to be mentioned 226 times in the analyzed genres. The most frequently repeated value was found to be love (50), followed by kindness (27), patriotism (17), sharing (15), altruism (13), happiness (11), helping each other (10), respect (10), friendship (8), freedom (7), being moral (7), courage (6), solidarity (5), honesty (5), hospitality (5), paying attention to family unity (5), heroism (4), mercy (4), modesty (3), fellowship (3), brotherhood (2), being responsible (2), being just (1), tolerance (1), health (1), cleanliness (1), peace (1), patience (1), national solidarity (1). The highest number of values were mentioned in stories while the smallest number of values were mentioned in comics.

\section{Discussion}

The most frequently mentioned value in the literary texts analysed in the current study is love. In the related literature, there are studies investigating 100 basic literary works (Şen, 2007), stories (Özbay and Tayşi, 2011) and children's books (Karagöz, 2018) in terms of values they have, and in these studies it is seen that the value of love is emphasized more. Bringing this value to the fore while teaching children can be supportive for the adoption of other values (Candan and Ergen, 2014, p.155).

The most frequently mentioned value after love was found to be kindness in the current study. In their study on picture story and folk tale books, Turan and Ulutaş (2016); in their study investigating values in story and folk tale books, Cengiz and Duran (2017) and in his study on picture books for children aged 3-6, Dirican (2013) also found that the value of kindness is frequently emphasized. The kindness of heroes in literary texts can be a good role model for children.

In the current study, peace, tolerance, national solidarity, health, cleanliness and patience were found to be the values least frequently mentioned. Similarly, these values were reported to be less frequently mentioned values in some other studies (Güven, 2004; Turan and Ulutaş 2016; Eker and Yıldırım 2017; Cengiz and Duran, 2017).

As a conclusion, in the current study conducted to determine which values are mentioned in the story, folk tale and comics genres in the children's magazine "Sevgi Bir Kuş", the most frequently mentioned values were found to be love, kindness, patriotism and sharing. If children empathise with the good characteristics of heroes and take the behaviours exhibited by them as a model to themselves while reading children's magazines, it can be good for them to internalize universal and social values. Finally, it can be suggested that more emphasis should be put on values less frequently mentioned in the magazine "Sevgi Bir Kuş" such as peace, tolerance, national solidarity, being just, health, cleanliness and patience, that more values should be addressed in comics having visual content and supporting these values with visual elements will make the magazine more effective in the transfer of values. Moreover, in 
future research, literary genres in the magazine can be analyzed in terms of positive and negative contents, the visuals in the magazine can be analyzed in terms of their appropriacy for children and national and religious elements in the literary genres in the magazine can be investigated.

\section{Araştırmanın Etik Taahhüt Metni}

Yapılan bu çalışmada bilimsel, etik ve alıntı kurallarına uyulduğu; toplanan veriler üzerinde herhangi bir tahrifatın yapılmadığı, karşılaşılacak tüm etik ihlallerde "Cumhuriyet Uluslararası Eğitim Dergisi ve Editörünün" hiçbir sorumluluğunun olmadığ1, tüm sorumluluğun Sorumlu Yazara ait olduğu ve bu çalışmanın herhangi başka bir akademik yayın ortamına değerlendirme için gönderilmemiş olduğu sorumlu yazar tarafından taahhüt edilmiştir.

\section{Authors' Biodata/ Yazar Bilgileri}

Ceylan TEKİN BAHRİLLİ Üsküdar Üniversitesi Çocuk Gelişimi Bölümü Yüksek Lisans öğrencisidir. Aile Çalışma ve Sosyal Hizmetler Bakanlığında çocuk gelişimci olarak çalışmaktadır.

Ceylan Tekin Bahrilli she is a postgraduate student at Uskudar University, Department of Child Development. She works as a child development specialist at Ministry of Family, Labour and Social Services

Cennet Göloğlu DEMİR Bandırma Onyedi Eylül Üniversitesi Sağlık Bilimleri Fakültesi Çocuk Gelişimi Bölümü'nde Dr. Öğretim Üyesi olarak görev yapmaktadır.

Cennet Göloğlu Demir works as an Assistant Professor at Bandirma Onyedi Eylul University, Faculty of Health Sciences, Department of Child Devolopment 